\title{
Immune Function in Systemic Lupus Erythematosus
}

\author{
IMPAIRMENT OF IN VITRO T-CELL PROLIFERATION \\ AND IN VIVO ANTIBODY RESPONSE TO EXOGENOUS ANTIGEN
}

\author{
A. B. Gottlieb, R. G. Lahita, N. Chiorazzi, and H. G. Kunkel, The Rockefeller \\ University, New York 10021
}

A в S T RACT Peripheral blood mononuclear cells from 46 systemic lupus erythematosus (SLE) patients showed reduced ability to proliferate in vitro in response to the soluble antigen, tetanus toxoid, as compared with 96 normal controls. Special studies of 27 untreated SLE patients also revealed significantly decreased blastogenic responses to tetanus toxoid. In both the total and untreated SLE populations, decreased mean tetanus antibody titers also were found as compared with the control population. However, the reduction in antibody titer and blastogenic response was not strictly parallel. A limited immunization program was initiated in lowresponding volunteers from the SLE and normal populations. Three out of four SLE patients did not develop a significant blastogenic response despite increases in anti-tetanus titers after immunization, whereas all normals showed significant increases in both blastogenic and antibody responses. The accumulated evidence indicated that the unresponsiveness was the result of a defect in T-cell function. Monocyte reactivity was demonstrated to be normal, and no evidence was found for the presence of suppressor cells, inhibition by immune complexes, or increased prostaglandins to explain the defect.

\section{INTRODUCTION}

Considerable current interest has been focused on the possibility T-cell alterations in patients with systemic lupus erythematosus $(\mathrm{SLE})^{1}$ playing a significant role in the immunological alterations characteristic

Dr. Lahita is a Clinical Scholar at The Rockefeller University. Dr. Chiorazzi is a recipient of a fellowship from the Arthritis Foundation.

Received for publication 22 November 1978 and in revised form 10 January 1979.

${ }^{1}$ Abbreviations used in this paper: $\mathrm{E}_{\mathrm{N}}$, neuraminidasetreated sheep erythrocytes; Fr II, fraction II; M $\emptyset$, monocytes; PBMC, peripheral blood mononuclear cells; PHA, phytohemagglutinin; SLE, systemic lupus erythematosus; TT, tetanus toxoid. of this disease. Although many groups have studied this question and some evidence for this possibility has been obtained (1-5), the literature to date is confusing. For example, two reports on the blastogenic response of $T$ cells to antigen stimulation have drawn completely opposite conclusions $(6,7)$, and it was recently reported that impaired cellular immune function was the result solely of steroid therapy (7). Contributing factors to the conflicting reports include differences in patient selection, effects of drug therapy on cellular immune function, and technical variability of in vitro assays. Recent interest in these questions has intensified in view of recent reports suggesting a decrease of suppressor cells in SLE patients $(8,9)$.

Previous studies from our laboratory had indicated T-cell defects in studying the response of $T$ lymphocytes in mixed leukocytic culture reactions (10) and in the release of migration inhibiting factor to measles antigen (11) in SLE patients. The present studies were undertaken to define more completely the $\mathrm{T}$-cell response to antigen in these patients, employing the tetanus toxoid system that has long been studied in this laboratory for other purposes. In addition, it was planned to examine antibody responses at the same time and attempt to relate these to T-cell function.

\section{METHODS}

Cell isolations. Peripheral blood mononuclear cells (PBMC) were isolated on Ficoll-Hypaque (Ficoll, Pharmacia Fine Chemicals, Piscataway, N. J., Hypaque, Winthrop Laboratories, New York) density gradients followed by four washes in phosphate-buffered saline. $T$ cells were isolated from PBMC on Ficoll-Hypaque gradients according to their capacity to form rosettes with neuraminidase-treated sheep erythrocytes $\left(E_{N}\right)$ and were quantified by $E_{N}$-rosetting as described (12). Isolated $\mathrm{T}$ cells were always $>90 \%$ pure and non-T-cell fractions were typically $20-30 \%$ B cells, $60-70 \%$ monocytes, and $1-10 \%$ T cells. Monocytes were isolated from PBMC by adherence onto plastic microtiter plates in RPMI 1640 (Microbiological Associates, Walkersville, Md.)-10\% fetal calf serum. $0.05 \mathrm{ml} \mathrm{PBMC} / 6-\mathrm{mm}$ microtiter well were adhered for $90 \mathrm{~min}$ at $37^{\circ} \mathrm{C}$ in a $5 \% \mathrm{CO}_{2}$ atmosphere, followed by two washes 
with phosphate-buffered saline (13). The adherent layers were typically $>90 \%$ peroxidase positive.

Cell cultures. Cells were cultured in flat-bottomed microtiter plates (Linbro Chemical Company, Hamden, Conn.) at $1-2 \times 10^{5}$ cells per culture in RPMI 1640 supplemented with $20 \%$ normal human $\mathrm{AB}$ serum plus glutamine $(2 \mathrm{mM})$ and penicillin-streptomycin $(100 \mathrm{U} / \mathrm{ml})$. Tetanus toxoid (TT) (State Laboratory Institute, Jamaica Plain, Mass.) was added at a final concentration of $40 \mu \mathrm{g} / \mathrm{ml}$ and phytohemagglutinin (PHA; Burroughs Wellcome Co., Research Triangle Park, N. C.) was added at a final concentration of $1 \%$. All cultures were done in triplicate. $2 \mu \mathrm{Ci}$ of $\left[{ }^{3} \mathrm{H}\right]$ thymidine (Schwarz/ Mann Div., Becton, Dickinson \& Co., Orangeburg, N. Y.) were added per $0.25 \mathrm{ml}$ of culture after $5 \mathrm{~d}$ for TT and after $2 \mathrm{~d}$ for PHA. The cultures were harvested $16 \mathrm{~h}$ later and counted in a liquid scintillation counter. Mixed leukocyte cultures were performed as in Wernet and Kunkel (10).

Miscellaneous. Hemagglutination of TT-coated human erythrocytes by plasma or serum was performed as described in Ling et al. (14).

Fraction II (Fr II) was isolated by DEAE chromatography. Purified Fr II was spun at $40,000 \mathrm{rpm}$ for $60 \mathrm{~min}$, and the top $2 \mathrm{ml}$ of supernate was removed. This fraction was monomeric Fr II. The remainder was aggregated by heating at $62^{\circ} \mathrm{C}$ for $20 \mathrm{~min}$ followed by spinning at $8,000 \mathrm{rpm}$ for $30 \mathrm{~min}$ to remove large aggregates.

A stock solution of indomethacin (Sigma Chemical Co., St. Louis, Mo.) at $10 \mathrm{mg} / \mathrm{ml}$ was prepared in $95 \%$ ethanol. Further dilutions were made in phosphate-buffered saline. Statistical analyses were performed with the aid of Dr. Allan Gottlieb (York College, Albany, N. Y.) with Student's t distribution test.

Patients. All SLE patients fulfilled at least four of the American Rheumatism Association diagnostic criteria for SLE and had a positive antinuclear antibody test. They were seen at the outpatient clinic of The Rockefeller University Hospital during the period of study. This population consisted of $\mathbf{4 2}$ women and 4 men. Only those patients receiving no steroids, alkylating agents, or antimetabolites were considered as untreated. Patients were classified as active at the time of study if they demonstrated active nephritis (hematuria, pyuria, erythrocyte casts, increasing proteinuria or decreasing glomerular filtration rate, fluid retention, edema, hypertension, or azotemia), pulmonary (pleural effusion or pulmonary infiltrates), cardiovascular (pericarditis, myocarditis, thrombophlebitis), or central nervous system (psychosis, seizures) abnormalities not attributable to concurrent disease. Depressed serum hemolytic complement values, elevated anti-native DNA titers, elevated erythrocyte sedimentation rates, lymphopenia or thrombocytopenia were the primary parameters of disease activity utilized to distinguish recent activity from residua of previous activity.

Controls were recruited among Rockefeller University personnel. This group was approximately age matched with the SLE population and consisted of 59 women and 37 men.

For the immunization studies, volunteers were chosen among patients during relatively quiescent periods of their disease. Patients selected for immunization had no significant blastogenic response to TT and very low or negative TT antibody titers. It was hoped that this might be improved for the patients' benefit. All patients signed informed consent forms before immunization. Normal and SLE volunteers were immunized once with $0.5 \mathrm{ml}$ TT fluid (NDC 0002-2221-0; Eli Lilly \& Co., Indianapolis, Ind.) subcutaneously.

\section{RESULTS}

Blastogenic and antibody response of normal and SLE patients to TT. PBMC from normal and SLE pa- tients were cultured with TT for $5 \mathrm{~d} ;\left[{ }^{3} \mathrm{H}\right]$ thymidine was added, and the cultures were harvested $16 \mathrm{~h}$ later. Maximal $\left[{ }^{3} \mathrm{H}\right]$ thymidine incorporation by normal PBMC was achieved at $40 \mu \mathrm{g} / \mathrm{ml} \mathrm{TT}$. Increasing TT concentrations above $40 \mu \mathrm{g} / \mathrm{ml}$ usually resulted in a decline of $\left[{ }^{3} \mathrm{H}\right]$ thymidine incorporation. PBMC from SLE patients failed to respond to TT at concentrations ranging from 0.4 to $400 \mu \mathrm{g} / \mathrm{ml}$. Individuals with blastogenic responses of $10,000 \mathrm{cpm}$ or less were considered low responders. No low-responding normal or SLE patient converted to responder status by either lowering or raising the TT concentration from $40 \mu \mathrm{g} / \mathrm{ml}$. $\left[{ }^{3} \mathrm{H}\right] \mathrm{Thymidine}$ incorporation in the absence of antigen was similar for normal and SLE populations. Fig. 1 shows the blastogenic response of each patient in the normal, untreated, and treated SLE groups. 68 out of $96(70 \%)$ normal individuals demonstrated a response of $>10,000 \mathrm{cpm}$ to TT, whereas only 7 out of $27(26 \%)$ untreated SLE patients did similarly. Only 1 out of $8(13 \%)$ untreated active patients as compared with 6 out of $19(32 \%)$ inactive patients exhibited blastogenic responses $>10,000 \mathrm{cpm}$ to TT. 10 out of 19 treated SLE patients had active disease at the time of assay. For both inactive and active patients in this group, only $10 \%$ were responders to TT. Blastogenic response in the normal population ranged from 238 to $162,281 \mathrm{cpm}$. In untreated SLE patients, the range was 621 to $145,094 \mathrm{cpm}$ for inactive and 901 to

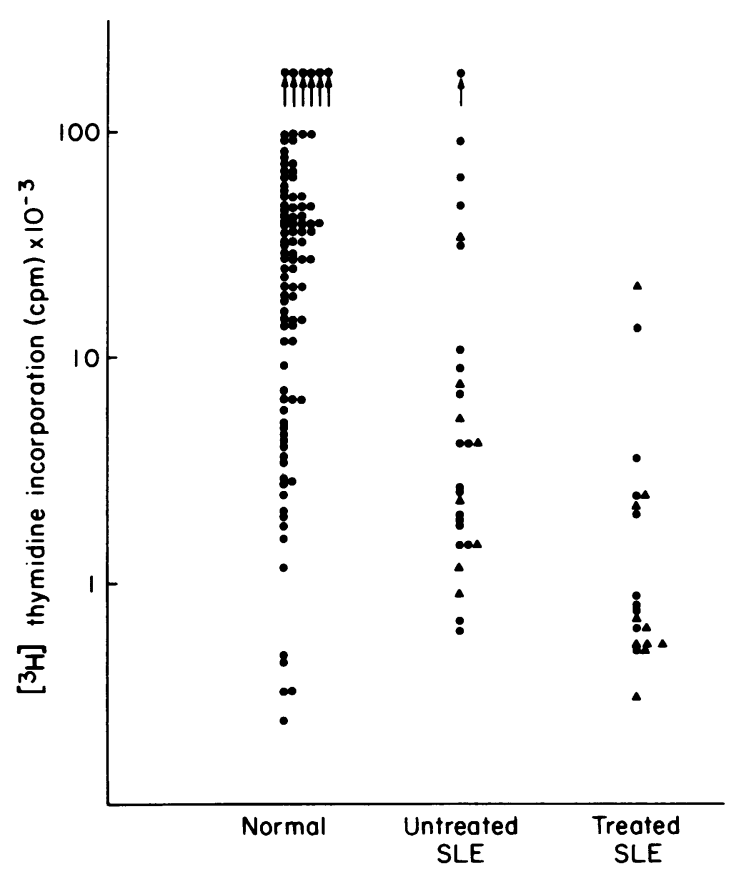

FIGURE 1 Blastogenic response to TT of normal and SLE PBMC: role of therapy and disease activity. Normal and SLE PBMC were cultured $5 \mathrm{~d}$ with TT. $\left[{ }^{3} \mathrm{H}\right]$ Thymidine was added, and the experiment was harvested $16 \mathrm{~h}$ later. Each point represents the blastogenic response of an individual patient: normal or inactive SLE; $\Delta$, active SLE. 
$34,982 \mathrm{cpm}$ for active patients. The blastogenic response of treated SLE patients ranged from 309 to $21,371 \mathrm{cpm}$. Table I summarizes these results. Data are presented as the natural log of counts per minute $\pm S D$ and natural $\log$ of antibody titer \pm SD in Tables I and II, respectively. 96 normals had a mean blastogenic response to TT of $9.77 \pm 1.59$ as compared with $7.97 \pm 1.55$ for the 46 SLE patients studied $(P<0.001)$. When the 27 untreated SLE patients were considered as one group, their mean response was significantly lower than that of the normals $(8.56 \pm 1.54, P<0.001)$. Both inactive and active SLE patients showed depressed mean blastogenic responses to TT; $8.71 \pm 1.67(P<0.02)$ and $8.18 \pm 1.20(P<0.01)$, respectively. Because the normal and SLE groups studied were not exactly comparable with regard to sex distribution, the blastogenic response of female SLE patients was compared with that of normal females, and the results are shown in Table I. 59 normal females had a mean blastogenic response of $9.89 \pm 1.42$ which was not significantly different from that of normal males $(P>0.4)$. Both the total population of female SLE patients and untreated SLE females showed depressed mean blastogenic responses to TT; $7.80 \pm 1.48(P<0.001)$ and $8.37 \pm 1.47(P<0.001)$, respectively. SLE patients receiving steroids, alkylating agents, or antimetabolites showed a lower mean blastogenic response to TT than did untreated SLE patients $(P<0.01)$. The response to PHA in all groups of SLE patients, regardless of

TABLE I

Decreased Blastogenic Response of SLE As Compared with Normal PBMC to TT: Role of Therapy and Disease Activity

\begin{tabular}{|c|c|c|c|}
\hline \multirow[b]{2}{*}{ Group } & \multirow{2}{*}{$\begin{array}{l}\text { Sample } \\
\text { size }\end{array}$} & \multicolumn{2}{|c|}{$\left[{ }^{3} \mathrm{H}\right]$ thymidine incorporation ${ }^{*}$} \\
\hline & & TT & PHA \\
\hline $\begin{array}{l}\text { Normal } \\
\text { SLE }\end{array}$ & 96 & $9.77 \pm 1.59$ & $11.69 \pm 0.71$ \\
\hline All patients & 46 & $\begin{array}{c}7.97 \pm 1.55 \\
(P<0.001) \S\end{array}$ & $\begin{array}{l}11.45 \pm 0.76 \\
(P>0.05) \oint\end{array}$ \\
\hline No therapy & 27 & $\begin{array}{r}8.56 \pm 1.54 \\
(P<0.001)\end{array}$ & $\begin{array}{l}11.57 \pm 0.73 \\
(P>0.4)\end{array}$ \\
\hline Inactive & 19 & $\begin{array}{l}8.71 \pm 1.67 \\
(P<0.02)\end{array}$ & $\begin{array}{l}11.40 \pm 0.80 \\
(P>0.1)\end{array}$ \\
\hline Active & 8 & $\begin{array}{l}8.18 \pm 1.20 \\
(P<0.01)\end{array}$ & $\begin{array}{l}11.96 \pm 0.32 \\
(P>0.2)\end{array}$ \\
\hline $\begin{array}{l}\text { Normal females } \\
\text { SLE females }\end{array}$ & 59 & $9.89 \pm 1.42$ & - \\
\hline All patients & 42 & $\begin{array}{r}7.80 \pm 1.48 \\
(P<0.001)\end{array}$ & 一 \\
\hline No therapy & 23 & $\begin{array}{r}8.37 \pm 1.47 \\
(P<0.001)\end{array}$ & - \\
\hline
\end{tabular}

* Mean (ln counts per minute) $\pm \mathrm{SD}$ in the presence of TT or PHA.

$\S$ Student's $t$ distribution test was used to calculate statistical significance.
TABLE II

Decreased Tetanus Antibody Titers in SLE As Compared with Normal Individuals

\begin{tabular}{lccc}
\hline \multicolumn{1}{c}{ Group } & Sample size & Antibody titer* & Significance \\
\hline & & & $P$ \\
Normal & 86 & $8.30 \pm 2.33$ & \\
SLE & & & \\
$\quad$ All patients & 43 & $4.58 \pm 3.37$ & $<0.001$ \\
$\quad$ No therapy & 25 & $5.09 \pm 3.47$ & $<0.001$ \\
Normal females & 54 & $7.67 \pm 2.36$ & \\
SLE females & 38 & $4.07 \pm 3.10$ & $<0.001$
\end{tabular}

* Mean (ln titer) \pm SD vs. TT-coated human erythrocytes where the titer is the reciprocal of the highest dilution of plasma or serum to give agglutination.

treatment or disease activity, was not significantly different from that of normals. For example, the mean response to PHA among normal individuals was 11.69 \pm 0.71 ; the mean of all SLE responses to PHA was $11.45 \pm 0.76(P>0.05)$.

TT antibody titers were measured by indirect hemagglutination with TT-coated human erythrocytes, and the results are shown in Table II. 86 normals had a mean antibody level of $8.30 \pm 2.33$ as compared with 25 untreated SLE patients who had a mean level of 5.09 $\pm 3.47(P<0.001)$. The total SLE population had a mean antibody level of $4.58 \pm 3.37$ ( $P<0.001)$. SLE females had significantly lower mean antibody levels than normal females. (Compare $4.07 \pm 3.10$ with $7.67 \pm 2.36$; respectively, $P<0.001$.)

Attempts to correlate antibody titer and blastogenic response to TT were undertaken to determine the relationship between cellular immunity as measured by $\left[{ }^{3} \mathrm{H}\right]$ thymidine incorporation and antibody response to antigen. The results for the SLE group are shown in Fig. 2. The correlation between blastogenic response

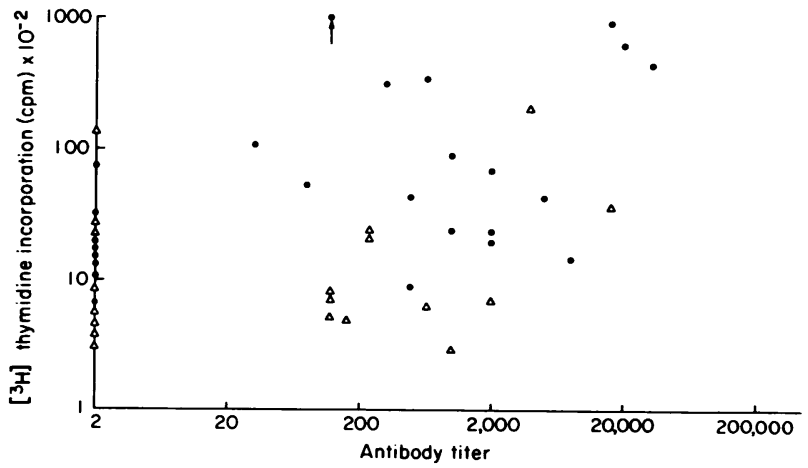

FIGURE 2 Poor relationship between blastogenic response and anti-TT titer in SLE patients: 0 , untreated; $\Delta$, treated. Blastogenic response of PBMC was measured by $\left[{ }^{3} \mathrm{H}\right]$ thymidine incorporation (see Fig. 1). Anti-TT titers were determined as in Table II. 
and antibody titer was poor in both the SLE and normal groups but was stronger in the SLE population than in the normals ( $r=0.42$ for SLE; $r=0.15$ for normal). Perhaps most striking in the SLE group was the complete absence of antibody in 16 of the 44 patients. This was found in only 2 of 88 controls. The zero antibody SLE group included both untreated and treated patients. Only one of these showed a blastogenic response above $10,000 \mathrm{cpm}$. Low blastogenic responses were also observed in many of the patients with very significant antibody levels.

Failure of immunization to restore SLE blastogenic response to TT in most cases. Previous studies of the effect of immunization on tetanus antibody titers have shown the response usually fell $10 \mathrm{yr}$ after immunization (15). Careful histories of the control and SLE individuals indicated that dissimilar immunization histories did not appear to account for differences observed. In addition, a limited immunization program was initiated in low-responder volunteers from each group. Individuals were immunized once with $0.5 \mathrm{ml}$ of TT fluid subcutaneously and then bled once a week for 1 mo after immunization. Fig. 3 shows the increase in cellmediated immunity of PBMC as measured by $\left[{ }^{3} \mathrm{H}\right]-$ thymidine incorporation, and the increase in anti-TT antibody titers as measured by indirect hemagglutina-

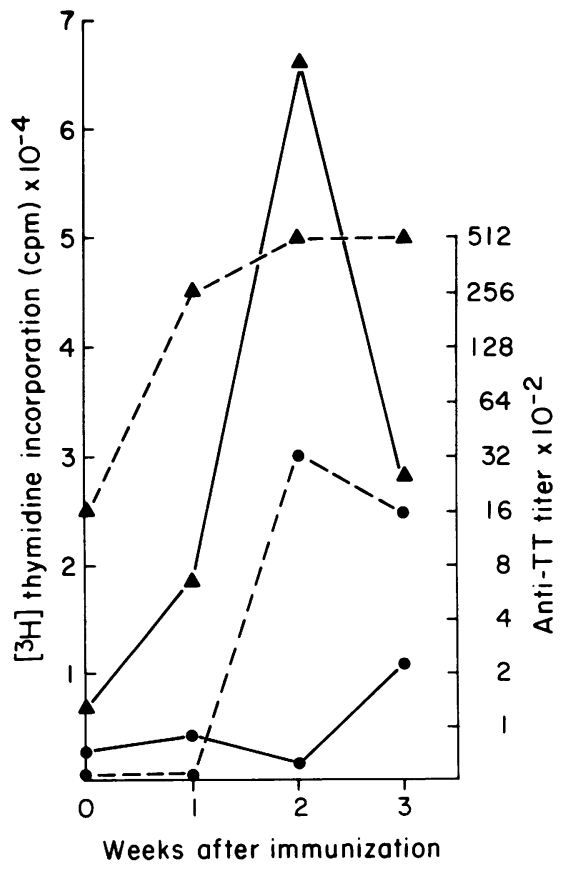

FIGURE 3 Deficient blastogenic response to immunization with TT in a low-responding SLE patient as compared with a low responding control; normal increase in anti-TT titers after immunization. Blastogenic response $(-)$ was measured as in Fig. 1. Anti-TT titers (-- ) were measured as in Table II. $\Delta$, normal; $\bigcirc$, SLE. tion of a low-responding normal and SLE patient as a function of time after immunization. Over the 3-wk time period studied, the normal low responder increased cellular immunity to TT from 6,962 to $66,099 \mathrm{cpm}$, whereas the SLE patient showed very little increase. The increase in anti-TT antibody titers was comparable to that of the normal. Later studies of this SLE patient showed continuous low blastogenic response to TT, indicating that this response was not simply delayed. Table III compares the highest blastogenic and antibody responses attained during the month after immunization with preimmunization values for different groups of SLE and normal individuals.

Seven normal individuals, with either low or high initial responses to TT, all showed marked increases in both blastogenic and antibody responses to TT after immunization. In contrast, three out of four SLE patients failed to show blastogenic responses to TT above 11,000 cpm despite normal increases in anti-TT titers after immunization. Only patient 3 was on therapy $(10 \mathrm{mg}$ prednisone every day), and all the patients were inactive clinically.

Requirement of monocytes $(M \Phi)$ by $T$ cells proliferating in response to TT: normal $M \emptyset$ function in $S L E$ blastogenic response to TT. In vitro studies of cellular immunity in guinea pigs and mice demonstrated a requirement for $\mathrm{M} \phi$ by $\mathrm{T}$ cells proliferating in response to a variety of protein antigens $(16,17)$. The need for $\mathrm{M} \emptyset$ in the blastogenic response to TT was investigated by adding $T$ cells and adherent cells together at the initiation of culture with TT. $\left[{ }^{3} \mathrm{H}\right]$ Thymidine was added $5 \mathrm{~d}$ later, and the cultures were harvested $16 \mathrm{~h}$ later. In a representative experiment, PBMC gave a blastogenic response to TT of $68,253 \mathrm{cpm}$ and adherent cells alone, $903 \mathrm{cpm}$. In the absence of adherent cells, $T$ cells gave a blastogenic response of only $3,045 \mathrm{cpm}$. Adding back adherent cells increased $\left[{ }^{3} \mathrm{H}\right]$ thymidine incorporation to $149,460 \mathrm{cpm}$. In other experiments, it was shown that depleting $\mathrm{M} \emptyset$ from PBMC by carbonyl iron ingestion before adherence onto microtiter wells obliterated adherent cell ability to help T-cell proliferation in response to TT.

It was possible that the inability of SLE patients to respond to TT was the result of $M \emptyset$ dysfunction. Immune complexes bound to $M \emptyset \mathrm{Fc}$ receptors might have paralyzed $M \emptyset$ function. In addition, $M \emptyset$-reactive antibodies have been reported in SLE patients (18). Preliminary experiments with normal individuals indicated the requirement for $T$ cells and $M \emptyset$ to be syngeneic to generate blastogenic responses to TT. To determine whether T cells or $M \emptyset$ were defective in SLE response to TT, histocompatible SLE and normal individuals were studied. The results are shown in Table IV. P.J. (HLA 1,8/1,8), an SLE patient, is histocompatible with her normal sister, Ei.J. (HLA 1,8/1,8). P.J.'s PBMC showed poor response to TT ( $161 \mathrm{cpm})$, whereas Ei.J.'s 
TABLE III

Failure of Immunization with TT to Restore the Majority of SLE Blastogenic Responses to TT Despite a Rise in Anti-tetanus Antibody Titers

\begin{tabular}{|c|c|c|c|c|}
\hline \multirow[b]{2}{*}{ Patient } & \multicolumn{2}{|c|}{ Preimmune response } & \multicolumn{2}{|c|}{ Peak postimmune response } \\
\hline & $\begin{array}{l}{\left[{ }^{3} \mathrm{H}\right] \text { Thymidine }} \\
\text { incorporation* }\end{array}$ & $\begin{array}{c}\text { Anti-TT } \\
\text { titer }\end{array}$ & $\begin{array}{l}{\left[{ }^{3} \mathrm{H}\right] \text { Thymidine }} \\
\text { incorporation* }\end{array}$ & $\begin{array}{c}\text { Anti-TT } \\
\text { titert }\end{array}$ \\
\hline & $c p m$ & & $c p m$ & \\
\hline \multicolumn{5}{|l|}{ Normal } \\
\hline \multicolumn{5}{|c|}{ Low responder } \\
\hline $1(q)$ & 6,962 & 1,600 & 66,099 & 51,200 \\
\hline $2(q)$ & 12,128 & 1,600 & 27,432 & 25,600 \\
\hline \multicolumn{5}{|l|}{ Responder } \\
\hline $3(q)$ & 36,304 & 8,000 & 141,787 & $1,024,000$ \\
\hline $4(\delta)$ & 56,005 & 64,000 & 129,666 & $2,048,000$ \\
\hline $5(q)$ & 49,081 & 64,000 & 129,742 & 256,000 \\
\hline $6(\delta)$ & 40,602 & 64,000 & 194,675 & $2,048,000$ \\
\hline \multicolumn{5}{|c|}{ First immunization } \\
\hline $7(q)$ & 2,728 & $<10$ & 31,811 & 32 \\
\hline \multicolumn{5}{|l|}{ SLE } \\
\hline \multicolumn{5}{|c|}{ Low responder } \\
\hline$I(q)$ & 2,580 & $<10$ & 10,782 & 3,200 \\
\hline $2(\%)$ & 199 & $<10$ & 5,263 & 5,120 \\
\hline $3(q)$ & 2,479 & 256 & 10,529 & 32,000 \\
\hline $4(q)$ & 5,843 & 80 & 40,634 & 20,480 \\
\hline
\end{tabular}

* PBMC were cultured $5 \mathrm{~d}$ with TT; $\left[{ }^{3} \mathrm{H}\right]$ thymidine was added, and the cultures were harvested $16 \mathrm{~h}$ later.

\$ Reciprocal of the highest dilution of plasma or serum to give agglutination with TT-coated human erythrocytes.

PBMC proliferated well $(22,964 \mathrm{cpm})$. Both sisters' $T$ cells failed to respond to TT without $M \emptyset$ help (Table IV, lines 3 and 4). P.J.'s M $\emptyset$ were equal to Ei.J's $\mathrm{M} \emptyset$ in cooperating with Ei.J.'s T cells to make a good proliferative response to TT (Table IV, lines 9 and 10). P.J.'s $\mathrm{T}$ cells failed to respond

TABLE IV

SLE Patients Have Normal M $\emptyset$ Ability to Help T Cells Proliferate in Response to TT

\begin{tabular}{|c|c|c|c|c|}
\hline \multicolumn{3}{|c|}{ Cell populations } & \multicolumn{2}{|c|}{$\begin{array}{c}{\left[{ }^{3} \mathrm{H}\right] \text { Thymidine }} \\
\text { incorporation }\end{array}$} \\
\hline PBMC & $\mathrm{T}$ & $\mathbf{M} \emptyset$ & TT & No TT \\
\hline & & & \multicolumn{2}{|c|}{$c p m$} \\
\hline Ei.J. & 一 & 一 & 22,964 & 208 \\
\hline P.J. (SLE) & - & - & 161 & 377 \\
\hline - & Ei.J. & 一 & 248 & 112 \\
\hline 一 & P.J. & - & 206 & 112 \\
\hline - & - & Ei.J. & 99 & 186 \\
\hline - & - & P.J. & 105 & 124 \\
\hline - & P.J. & P.J. & 270 & 293 \\
\hline - & P.J. & Ei.J. & 207 & 168 \\
\hline - & Ei.J. & Ei.J. & 15,700 & 1,048 \\
\hline - & Ei.J. & P.J. & 21,302 & 1,519 \\
\hline
\end{tabular}

even when a normal syngeneic $\mathrm{M} \emptyset$ source was added (Table IV, lines 7 and 8).

Miscellaneous studies. $\mathrm{T}$ cells suppress immune function in mice with poor response to certain synthetic antigens (19). To investigate the possibility that low response to TT was because of the presence of suppressor cells, normal, responding PBMC were mixed with histocompatible cells from an SLE patient. The results are shown on Table V. Addition of syngeneic SLE PBMC, $T$ cells, or non- $T$ cells, at three different concentrations, failed to alter the blastogenic response of normal PBMC to TT.

Aggregated or monomeric Fr II was added to PBMC of a normal responder to TT to mimic the effect of immune complexes on $\mathrm{T}$-cell function. Over a concentration range of from 1 to $200 \mu \mathrm{g} / \mathrm{ml}$, the response of normal $\mathrm{PBMC}$ in the presence of aggregated or monomeric Fr II was identical.

Recently, it was reported that glass wool-adherent lymphocytes secreted prostaglandins that suppressed the blastogenic response to PHA in normal individuals and in patients with Hodgkin's disease (20). Indomethacin, an irreversible inhibitor of prostaglandin synthetase, was added to cultures of TT and PBMC from four SLE patients. Concentrations up to $10 \mu \mathrm{g} / \mathrm{ml}$ failed to significantly enhance SLE blastogenic response to TT. 
TABLE V

SLE PBMC Do Not Inhibit Normal Proliferative Responses to TT

\begin{tabular}{|c|c|c|c|}
\hline \multicolumn{2}{|c|}{ Cell populations } & \multicolumn{2}{|c|}{$\begin{array}{l}{\left[{ }^{3} \mathrm{H}\right] \text { Thymidine }} \\
\text { incorporation* }\end{array}$} \\
\hline SLE P.J. & Normal Ei.J. & $\mathrm{TT}$ & No TT \\
\hline & & \multicolumn{2}{|c|}{$c p m$} \\
\hline - & $1.5 \times 10^{5} \mathrm{PBMC}$ & 22,964 & 208 \\
\hline $1.5 \times 10^{5} \mathrm{PBMC}$ & - & 161 & 377 \\
\hline $2 \times 10^{5} \mathrm{PBMC}$ & $1.5 \times 10^{5} \mathrm{PBMC}$ & 29,427 & 803 \\
\hline $1 \times 10^{5} \mathrm{PBMC}$ & $1.5 \times 10^{5} \mathrm{PBMC}$ & 39,483 & 980 \\
\hline $0.5 \times 10^{5} \mathrm{PBMC}$ & $1.5 \times 10^{5} \mathrm{PBMC}$ & 33,437 & 922 \\
\hline $2 \times 10^{5}$ non- $T$ & $1.5 \times 10^{5} \mathrm{PBMC}$ & 20,320 & 810 \\
\hline $1 \times 10^{5}$ non- $T$ & $1.5 \times 10^{5} \mathrm{PBMC}$ & 23,815 & 706 \\
\hline $0.5 \times 10^{5}$ non- $T$ & $1.5 \times 10^{5} \mathrm{PBMC}$ & 22,015 & 575 \\
\hline $2 \times 10^{5} \mathrm{~T} \ddagger$ & $1.5 \times 10^{5} \mathrm{PBMC}$ & 28,872 & 713 \\
\hline $1 \times 10^{5} \mathrm{~T}$ & $1.5 \times 10^{5} \mathrm{PBMC}$ & 27,796 & 277 \\
\hline $0.5 \times 10^{5} \mathrm{~T}$ & $1.5 \times 10^{5} \mathrm{PBMC}$ & 29,063 & 221 \\
\hline
\end{tabular}

* Cells were cultured $5 \mathrm{~d}$ with TT; $\left[{ }^{3} \mathrm{H}\right]$ thymidine was added, and the cells were harvested $16 \mathrm{~h}$ later.

$\ddagger$ PBMC were subjected to $\mathrm{E}_{\mathrm{N}}$-rosetting and the non- $\mathrm{T}$ (interphase) and $\mathrm{T}$ (pellet)-cell fractions obtained. T cells were $95 \%$ $\mathrm{E}_{\mathrm{N}}$-rosette positive.

At $100 \mu \mathrm{g} / \mathrm{ml}$, the nonspecific toxic effects of indomethacin were observed, as evidenced by a fall in $\left[{ }^{3} \mathrm{H}\right]$ thymidine incorporation seen in some of the patients tested.

\section{DISCUSSION}

Evidence for reduced cellular immunity to TT in SLE as compared with normal individuals has been presented. Defective blastogenesis was seen in the total and untreated SLE populations. Comparison of SLE females with normal females also revealed decreased blastogenesis. These studies extend previous work from this laboratory on decreased SLE cellular immune responsiveness in mixed leukocyte cultures (10) and in leukocyte migration inhibition assays (11). The current observations are in agreement with the results of Rosenthal and Franklin (6) and Horwitz (3) with different antigens. They differ from the recent report of Utsinger (7) who attributed decreased blastogenic response to antigen in SLE entirely to steroid therapy. A possible explanation for his different results is the use of fetal calf serum in the culture system. Our experience has indicated a considerable advantage in using human $\mathrm{AB}$ serum. It is known that corticosteroid administration causes diminished proliferative responses to TT and decreases the number of circulating $M \emptyset$ and T cells (21). Further evidence for such effects was obtained in the present study. It was therefore essential to study primarily a group of untreated SLE patients. Defects in the blastogenic responses of these individuals were observed.
Clear evidence was gained in this study for reduced levels of antibody to TT in the SLE group. This was especially striking in certain patients; $36 \%$ had no detectable antibody, as compared with only $2 \%$ in the control group. Too few observations were made in the present study to determine the direct antibody response to TT, a project difficult to carry out in untreated patients; the few patients studied showed an antibody response to TT. It could be that the SLE cases lose their antibody titer more readily than normals and that this is the explanation of the low levels encountered. Previous studies of SLE antibody response to immunization have been conflicting. SLE patients showed normal responses to immunization with influenza (22-24), TT (1), Brucella and Rickettsia (25), and had normal levels of antibodies to $\mathrm{AB}$ blood group antigens and Proteus OX-2 (26). In other studies, decreased SLE antibody responses were found upon immunization with influenza (27) and Brucella (28). SLE patients showed decreased levels of antibodies to streptolysin $\mathrm{O}(26)$ and of natural antibodies to Escherichia coli and Shigella antigens (28). On the other hand, elevated SLE antibody responses were found against penicillin (29), blood group antigens (30), and a variety of viral antigens (3135). It will be of interest to continue these antibody studies especially with more quantitative techniques and defining the class of immunoglobulin primarily involved.

Despite the reduction in antibody titer and blastogenic response in the SLE group, the two parameters were not strictly parallel in individual cases and the calculated correlation was not high. This was brought out further in the limited immunization studies in SLE patients. Each of four cases developed a significant rise in antibody titer, whereas only one showed a blastogenic response. Each of seven immunized controls showed a rise in both assays.

The low level of correlation of proliferative and antibody response to TT in normal individuals highlights the problem of how T-cell proliferative response to antigen relates to helper $T$-cell function. The literature to date is conflicting as to whether these functions are mediated by the same cell. TT has been shown to induce in vitro production of antigen-specific and nonspecific helper factors for antibody synthesis (36-38). Release of nonspecific helper factors, mitogenic for human bone marrow-derived (B) cells, was shown to correlate with the degree of lymphocyte proliferation in response to TT. Irradiation of lymphocytes prevented release of these factors (37). However, other studies have indicated that the helper $\mathrm{T}$ cell and the antigen-reactive, proliferating $\mathrm{T}$ cell might not be the same cell (39-41).

Because it is known that in addition to $T$ cells, the blastogenic response to antigen requires macrophages, it was important to show that a defect in these cells was not responsible for the reduced proliferation ob- 
served with the SLE cells. The system used in the present study was found to be completely $M \emptyset$ dependent with a requirement for syngeneic $M \emptyset$. Through the study of an HLA-identical sibling of an SLE patient with a very low response, it was evident that the SLE $\mathbf{M} \emptyset$ showed normal activity in facilitating proliferation of the sibling's $T$ cells.

The relationship of depressed immunity to TT and SLE disease activity remains uncertain. Untreated active or inactive patients, considered as separate groups, showed depressed blastogenic responses to TT. It was not possible to compare the untreated active with the inactive group because of sample size. Neither $\left[{ }^{3} \mathrm{H}\right]-$ thymidine incorporation by SLE PBMC in response to TT or anti-TT titers showed any obvious correlation with lymphocyte count, depressed serum hemolytic complement, or elevated erythrocyte sedimentation rate values.

The mechanisms of decreased T-cell proliferation in response to TT remain unknown. Antilymphocyte antibodies from SLE patients have been reported to inhibit antigen and mitogen reactivity of autologous and homologous lymphocytes $(10,42)$. However, serum samples from the vast majority of SLE patients failed to inhibit normal blastogenic responses to TT. It is possible that some SLE patients produce high affinity antilymphocyte antibodies that fix in vivo to antigen-responsive $T$ cells and eliminate them from the circulation despite inability to detect these antibodies in vitro. Despite some reduction in lymphocyte count, the percentage of $T$ cells was normal for most SLE patients studied. T-cell unresponsiveness to antigen might be caused by a failure of soluble factor production or an inability to recognize antigen. Immune complexes did not appear to account for decreased reactivity. Aggregated Fr II failed to inhibit a normal proliferative response to TT. Addition of SLE sera, known to contain immune complexes by Raji radioimmunoassay and analytical ultracentrifugation, did not inhibit the proliferative response of normal PBMC to TT. Just how the defect in T-cell response to TT relates to other T-cell abnormalities, such as a decrease in suppressor cells, is not clear. The T-cell populations involved in these two systems are entirely different (43). It seems possible that a general T-cell defect is present in these patients. However, assays of allogeneic helper factor generation, another test of T-cell function (44), was found to be normal. Further studies are required to determine these relationships.

\section{ACKNOWLEDGMENTS}

We thank Dr. Leo Levine for his donation of TT. The authors are grateful to Doctors Richard Stern, John Winfield, Hon-Sum Ko, Hal Whitman, Alan Gibofsky, Robert Winchester, Ghodrat Montazeri, Shu Man Fu, James Halper, Ira Berkower, and Frank Arena for their donations of patient material. We are indebted to Ms. Cabrini Delaney and Mr. Mark Laughlin for their excellent technical assistance.
This investigation was supported by U. S. Public Health Service grant AI-10811.

\section{REFERENCES}

1. Abe, T., and M. Homma. 1971. Immunological reactivity in patients with systemic lupus erythematosus. Humoral antibody and cellular immune responses. Acta Rheumatol. Scand. 17: 35-46.

2. Bitter, T., F. Bitter, R. Silberschmidt, and E. L. Dubois. 1971. In-vivo and in-vitro study of cell-mediated immunity (CMI) during the onset of systemic lupus erythematosus (SLE). Arthritis Rheum. 14: 152-153.

3. Horwitz, D. A. 1972. Impaired delayed hypersensitivity in systemic lupus erythematosus. Arthritis Rheum. 15: 353359.

4. Senyk, G., W. K. Hadley, M. R. Attias, and N. Talal. 1974. Cellular immunity in systemic lupus erythematosus. Arthritis Rheum. 17: 553-562.

5. Andrianakos, A. A., P. N. Tsichlis, E. G. Merikas, S. G. Marketos, J. T. Sharp, and G. E. Merikas. 1977. Cell mediated immunity in systemic lupus erythematosus. Clin. Exp. Immunol. 30: 89-96.

6. Rosenthal, C. J., and E. C. Franklin. 1975. Depression of cellular-mediated immunity in systemic lupus erythematosus. Relation to disease activity. Arthritis Rheum. 18: 207-217.

7. Utsinger, P. D. 1976. Lymphocyte responsiveness in systemic lupus erythematosus. Arthritis Rheum. 19: 88-92.

8. Bresnihan, B., and H. E. Jasin. 1977. Suppressor function of peripheral blood mononuclear cells in normal individuals and in patients with systemic lupus erythematosus. J. Clin. Invest. 59: 106-116.

9. Horowitz, S., W. Borcherding, A. V. Moorthy, R. Chesney, H. Schulte-Wissermann, R. Hong, and A. Goldstein. 1977. Induction of suppressor T cells in systemic lupus erythematosus by thymosin and cultured thymic epithelium. Science (Wash. D. C.). 197: 999-1001.

10. Wemet, P., and H. G. Kunkel. 1973. Antibodies to a specific surface antigen of $\mathrm{T}$ cells in human sera inhibiting mixed leukocyte culture reactions. J. Exp. Med. 138: 1021-1026.

11. Utermohlen, V., J. B. Winfield, J. B. Zabriskie, and H. G. Kunkel. 1974. A depression of cell-mediated immunity to measles antigen in patients with systemic lupus erythematosus. J. Exp. Med. 139: 1019-1024.

12. Hoffman, T., and H. G. Kunkel. 1976. The E-rosette test. In In Vitro Methods in Cell Mediated and Tumor Immunity. B. R. Bloom and J. R. David, editors. Academic Press Inc., New York. 71-81.

13. Johnson, W. D., Jr., B. Mei, and Z. A. Cohn. 1977. The separation and long-term cultivation and maturation of the human monocyte. J. Exp. Med. 146: 1613-1626.

14. Ling, N. R., S. Bishop, and R. Jeffris. 1977. Use of antibodycoated red cells for the sensitive detection of antigen and in rosette tests for cells bearing surface immunoglobulins. J. Immunol. Methods. 15: 279-289.

15. Stollerman, G. H. 1978. Bacterial vaccines and toxoids: Review of safety and efficacy. Adv. Intern. Med. 23: 408.

16. Rosenthal, A. S., and E. M. Shevach. 1973. Function of macrophages in antigen recognition. I. Requirement for histocompatible macrophages and lymphocytes. J. Exp. Med. 138: 1194-1212.

17. Yano, A., R. H. Schwartz, and W. E. Paul. 1977. Antigen presentation in the murine $\mathrm{T}$-lymphocyte proliferative response. I. Requirement for genetic identity at the major histocompatibility complex. J. Exp. Med. 146: 828-843.

18. Arend, W. P., T. E. Emmerich, J. C. Sturge, and G. A. Starkebaum. 1977. Monocyte-reactive antibodies in pa- 
tients with systemic lupus erythematosus. Arthritis Rheum. 20: 1049-1057.

19. Kapp, J. A., C. W. Pierce, S. Schlossman, and B. Benacerraf. 1974. Genetic control of immune responses in vitro. $\mathrm{V}$. Stimulation of suppressor $\mathrm{T}$ cells in nonresponder mice by the terpolymer L-glutamic acid ${ }^{60}$-L-alanine ${ }^{30}$-L-tyrosine ${ }^{10}$ (GAT). J. Exp. Med. 140: 648-659.

20. Goodwin, J. S., R. F. Messner, A. D. Bankhurst, G. T. Peake, J. H. Saiki, and R. C. Williams. 1977. Prostaglandinproducing suppressor cells in Hodgkin's disease. N. Engl. J. Med. 297: 963-968.

21. Fauci, A. S., and D. C. Dale. 1974. The effect of in vivo hydrocortisone on subpopulations of human lymphocytes. J. Clin. Invest. 53: 240-246.

22. Brodman, R., R. Gilfillan, D. Glass, and P. H. Schur. 1978. Influenzal vaccine response in systemic lupus erythematosus. Ann. Intern. Med. 88: 735-740.

23. Ristow, S. C., R. G. Douglas, Jr., and J. J. Condemi. 1978. Influenza vaccination of patients with systemic lupus erythematosus. Ann. Intern. Med. 88: 786-789.

24. Louie, J. S., K. M. Nies, K. T. Shoji, R. C. Fraback, C. Abrass, W. Border, J. D. Cherry, and D. Imagawa. 1978. Clinical and antibody responses after influenza immunization in systemic lupus erythematosus. Ann. Intern. Med. 88: 790-792.

25. Lee, S. L., L. E. Meiselas, S. B. Zingale, and R. Richman. 1960. Antibody production in systemic lupus erythematosus (SLE) and rheumatoid arthritis (RA).J. Clin. Invest. 39: 1005-1006.

26. Muschel, L. H. 1961. Systemic lupus erythematosus and normal antibodies. Proc. Soc. Exp. Biol. Med. 106: 622625.

27. Williams, G. W., A. D. Steinberg, J. L. Reinertsen, L. W. Klassen, J. L. Decker, and R. Dolin. 1978. Influenza immunization in systemic lupus erythematosus. A doubleblind trial. Ann. Intern. Med. 88: 729-734.

28. Baum, J., and M. Ziff. 1969. Decreased $19 S$ antibody response to bacterial antigens in systemic lupus erythematosus. J. Clin. Invest. 48: 758-767.

29. Harris, J., and J. Vaughan. 1960. Penicillin antibody in disease. J. Clin. Invest. 39: 995.

30. Zingale, S. B., A. J. C. Sanchez, J. A. Andrada, S. G. Stringa, and J. A. Manni. 1963. Appearance of anticoagulant factors and certain autoimmune antibodies following antigenic stimulation with blood group substances in patients with systemic lupus erythematosus. Arthritis Rheum. 6: 581-598.

31. Evans, A. S., and N. F. Rothfield. 1973. Virus and other viral antibodies in systemic lupus erythematosus. Lancet. I: 1127.
32. Wilson, C. B., F. J. Dixon, A. S. Evans, and R. J. Glassock. 1973. Antiviral antibody responses in patients with renal disease. Clin. Immunol. Immunopathol. 2: 121-132.

33. Hurd, E. R., W. Dowdle, H. Casey, and M. Ziff. 1972. Virus antibody levels in systemic lupus erythematosus. Arthritis Rheum. 15: 267-274.

34. Hollinger, F. B., J. T. Sharp, M. D. Lidsky, and W. E. Rawls. 1971. Antibodies to viral antigens in systemic lupus erythematosus. Arthritis Rheum. 14: 1-11.

35. Phillips, P. E., and C. L. Christian. 1971. Virus antibody studies in the connective tissue diseases. Arthritis Rheum. 14: $180-181$.

36. Geha, R. S., E. Schneeberger, F. S. Rosen, and E. Merler. 1978. Interaction of human thymus-derived and nonthymus-derived lymphocytes in vitro. Induction of proliferation and antibody synthesis in B lymphocytes by a soluble factor released from antigen-stimulated $\mathrm{T}$ lymphocytes. J. Exp. Med. 138: 1230-1247.

37. Geha, R. S., and E. Merler. 1974. Human lymphocyte mitogenic factor: synthesis by sensitized thymus-derived lymphocytes, dependence of expression on the presence of antigen. Cell. Immunol. 10: 86-104.

38. Mudawwar, F. B., E. J. Yunis, and R. S. Geha. 1978. Antigen-specific helper factor in man. J. Exp. Med. 148: 10321043.

39. Evans, R. L., T. J. Faldetta, R. E. Humphreys, D. M. Pratt, E. J. Yunis, and S. F. Schlossman. 1978. Peripheral human $\mathrm{T}$ cells sensitized in mixed leukocyte culture synthesize and express Ia-like antigens. J. Exp. Med. 148: 1440-1445.

40. Fu, S. M., N. Chiorazzi, C. Y. Wang, G. Montazeri, H. G. Kunkel, H. S. Ko, and A. B. Gottlieb. 1978. Ia-bearing $T$ lymphocytes in man. Their identification and role in the generation of allogeneic helper activity.J. Exp. Med. 148: 1423-1428.

41. Faith, R. E., M. I. Luster, and J. A. Moore. 1978. Chemical separation of helper cell function and delayed hypersensitivity responses. Cell. Immunol. 141: 275-284.

42. Horwitz, D. A., M. A. Garrett, and A. H. Craig. 1977. Serum effects on mitogenic reactivity in subjects with systemic lupus erythematosus, rheumatoid arthritis and scleroderma. Clin. Exp. Immunol. 27: 100-110.

43. Moretta, L., M. Ferrarini, and M. D. Cooper. 1978. Characterization of human $\mathrm{T}$ cell subpopulations as defined by specific receptors for immunoglobulins. Contemp. Top. Immunobiol. 8: 19-53.

44. Chiorazzi, N., S. M. Fu, G. Montazeri, H. G. Kunkel, K. Rai, and T. Gee. 1979. T-cell helper defect in patients with chronic lymphocytic leukemia. J. Immunol. 122: 1087-1090. 